\title{
Tournament Incentives and Frauds in the Financial Statements
}

\author{
Hidayatul Khusnah ${ }^{1, *}$ Niken Savitri Primasari ${ }^{2}$ \\ ${ }^{1}$ Accounting Department, Economic and Business Faculty, University of Nahdlatul Ulama Surabaya, Surabaya 60237, \\ Indonesia \\ ${ }^{*}$ Corresponding author. Email: hidayatul.khusnah@unusa.ac.id
}

\begin{abstract}
Incentive theory states that tournament incentives facilitate competition between senior executives, and that only the best will receive large monetary rewards, as well as a superior position in the corporate hierarchy. The purpose of this study was to investigate the effect of tournament incentives on the possibility of fraud in the financial statements of manufacturing companies listed on the Indonesian stock exchange. This study tested 63 data obtained from 7 companies for 6 consecutive years. The data analysis technique in this study used SEM-PLS analysis using the WarpPLS 5.0 software. The results of this study indicate that tournament incentives have a positive effect on the possibility of fraud in financial statements. The greater the level of competition to get a certain position, the greater the possibility of fraud in the financialstatements.
\end{abstract}

Keywords: tournament incentives, fraud

\section{INTRODUCTION}

Jensen and Meckling state that agency theory refers to managers tend to be more concerned with personal goals than company goals, namely maximizing the value obtained by shareholders, this is what underlies the conflict between managers and shareholders. This difference in interests will become a serious problem when no solution is immediately offered. One of the problems that arise is the decline in the value of the company so that it can have an impact on the decline in the company's stock price. The theory of tournaments was developed by Lazear and Rosen [1] which was later expanded by Rosen [1]. This theory states that tournament incentives facilitate competition between senior executives, and that only the best will receive large monetary rewards, as well as a superior position in the corporate hierarchy. Under the tournament scheme, executive performance is often evaluated by comparing how well each executive is performing compared to other executives who are involved in the competition [2], thus senior executives who have achieved the set targets will be who will win the competition. The large incentive payment gap between CEOs and non-CEO executives encourages these executives to make more efforts to achieve targets, one of which is promotion, therefore with tournament incentives it is possible for companies to retain high-performing executives [2]. Senior executives who win the competition will receive monetary incentives and promotion of strategic positions. To win the competition, senior executives must be able to achieve the targets that have been set, not infrequently in the process of achieving these targets senior executives commit unethical behavior.

There is an inconsistency from previous studies with regard to tournament incentives, in which there are two conflicting results. First, tournament incentives lead to negative managerial behavior for personal gain. Several studies such as that conducted by [3] show that tournament incentives can lead to greater managerial risk taking, Harbring and Irlenbusch also found that tournament incentives can lead to a higher tendency for errors in financial reporting, in addition to it also causes fraud in finance[4]. Jia [5] also found that the wage gap CEO and other senior executives also have positive influence on the share price fall rehearsal ang future will come. High 


\section{Procedia Business and Financial Technology}

Proceedings of the 2nd International Conference on Business and M anagement of T echnology (ICO N BM T 2020) - Part 2

incentives tournament lead senior executives tend to be tempted to commit unethical conduct in carrying out his work, so the effect on stock prices in the future will come. Second, the results of research that have contradicting results with the first, namely the results which show that tournament incentives have a positive effect on company performance. Competition for high incentives makes senior executives work harder so that it has a positive impact on company performance. This is also supported by a recent study conducted by Sun et al. [2] show that tournament incentives have a negative effect on the risk of falling share prices. The higher the tournament incentive, the lower the risk of falling share prices. Senior executives who are members of the competition will strive to improve their performance, so that it will affect the performance and share price of the company. Based on these two different research results, the researcher wanted to investigate further.

This study aims to investigate the effect of tournament incentives on the tendency of fraud in the financial statements of companies on the Indonesian stock exchange. This study tested 63 data obtained from 7 companies for 6 consecutive years. The data analysis technique in this study used SEM-PLS analysis using the WarpPLS 5.0 software. The results of this study indicate that tournament incentives have a positive effect on the possibility of fraud in financial statements. The greater the level of competition to get a certain position, the greater the possibility of fraud in the financial statements.

\section{LITERATURE REVIEW AND HYPOTHESIS}

\section{Development}

\section{Tournament Incentives with a tendency to fraud}

A group of executives usually work together in a team in a large company [5]. The group consists of CEOs and nonCEO executives who have relatively different levels of incentives. The incentive difference between CEOs and non-CEO executives will affect managerial behavior [6]. Non-CEO executives will respond positively to performance-based and promotion-based incentives, because there is an opportunity to be promoted to CEO, while CEOs will respond exclusively to performancebased incentives [7]. Non CEO executives who have good performance will have the opportunity to be promoted to CEO with a large additional incentive [1]. This will trigger an incentive gap between CEOs and non-CEO executives so that tournament incentives become even stronger [3].

Tournament incentives have a tendency for undesirable dysfunctional effects [5]. Several previous studies documented the negative effects of tournament incentives, including the occurrence of misreporting in financial reports, because executives manipulated $20 / 180$ financial reports in order to get promotion as CEO [8] , triggering fraud in financial reporting [4], and tends to increase the risk of falling stock prices [5].

Tournament incentives encourage executives to improve their performance in order to achieve the incentives offered. To achieve this target, executives often take deviant actions, which can be bad for the company. Based on previous research and the arguments above, the hypothesis proposed in this study are as follows:

H1: Tournament incentives have a positive effect on the tendency of fraud to occur.

Figure 1.1. conceptual framework

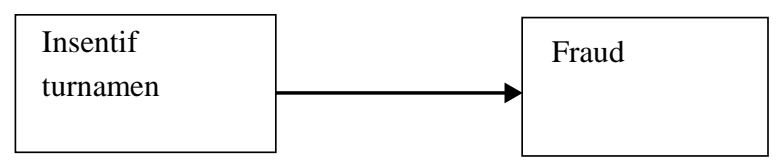

\section{METHODOLOGY}

This study tested 63 data obtained from 7 companies for 6 consecutive years. The data analysis technique in this study used SEM-PLS analysis using the WarpPLS 5.0 software .

\section{MEASUREMENT OF VARIABLES}

\section{Tournament Incentives}

The Tournament Incentives variable is proxied to be the executive pay gap. The executive pay gap in this study was measured using the Log (CEO-MedianVP Pay) measurement which was also used by previous researchers, namely [3], [5] . The executive pay gap is measured using the difference between the total compensation (the difference between the short- term and long-term compensation) of the company's CEO and the median value of the total compensation given annually by the company.

\section{Financial Statement Fraud}

The variable of Financial Statement Fraud in this study is measured using the $\mathrm{M}$ score model developed by Beneish using a dummy variable with two categories, namely 1 if the company is considered to have committed fraud in financial reporting and 0 if the company is deemed not to have committed fraud in financial reporting. This value is derived from the calculation of the M Score by category if the results tally $M$ score $>-2,22$, then the company is considered cheating in financial reporting. $M$ Score consists of eight indicators, namely DSRI, GMI, AQI, SGI, DEPI, TATA, SGAI, and LVGI. 


\section{Procedia Business and Financial Technology}

Proceedings of the 2nd International Conference on Business and M anagement of T echnology (ICO N BM T 2020) - Part 2

The following is the $\mathrm{M}$ score formula according to Beneish (1990):

\section{Score =}

$4,840+0,920$ DRSI + 0,528 GMI + 0,404 AQI + 0, 892 SGI + 0,115 DEPI - 0,172 SGAI - 0 , 327 LVGI + 4, 697 TATA

The following is

Day "s Sales in Receivable Index (DSRI)

This variable is the ratio between sales and receivables from the first year and the second year, measuring whether the income and accounts receivable balance for two consecutive years. The following is the formula for calculating the DSRI ratio based on Beneish (1999):

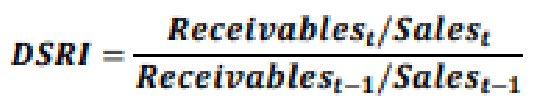

\section{Gross Margin Index (GMI)}

Gross margin index (GMI) is the ratio of sales minus selling, general and administrative expenses for sales in year $\mathrm{t}$ against the same ratio in year $\mathrm{t}-1$. The formula for calculating the GMI ratio is as follows (Beneish, 1999):

$$
G M I=\frac{\left(\text { Sales }_{t-1}-\text { COGS }_{t-1}\right) / \text { Sales }_{t-1}}{\left(\text { Sales }_{t}-\text { COGS }_{t}\right) / \text { Sales }_{t}}
$$

\section{Asset Quality Index (AQI)}

Asset Quality Index is the ratio of noncurret assets other than property, plant, equipment (PP\&E) assets to total assets. The higher the ratio, the more likely it is for the company to collect costs. The following is the formula for calculating the AQI ratio based on Beneish (1999):

$A Q I=\frac{1-\left(\text { Current asset }_{t}+\text { Fixed Assets }_{t}\right) / \text { Total Assets }_{t}}{1-\left({\text { Current } \text { asset }_{t-1}+\text { Fixed Asset }}_{t-1}\right) / \text { Total Assets }_{t-1}}$

\section{Sales Growth Index (SGI)}

Sales Growth Index ( Index Sales Growth) is the ratio between sales in year $t$ with sales in year $\mathrm{t}-1$. The following is the formula for calculating the SGI ratio based on Beneish (1999):

$$
S G I=\frac{\text { Sales }_{t}}{\text { Sales }_{t-1}}
$$

\section{Depreciation Index (DEPI)}

The depreciation rate in a given year equals depreciation / (depreciation + Net PP\&E). The formula for calculating the DEPI ratio is as follows (Beneish, 1999):

$$
D E P I=\frac{\left[\text { Depreciation }_{t-1} /\left(\text { PPE }_{t-1}+\text { Depreciation }_{t-1}\right)\right]}{\left[\text { Depreciation }_{t} /\left(\text { PPE }_{t}+\text { Depreciation }_{t}\right)\right]}
$$

\section{Sales General and Administrative Expenses Index (SGAI)}

The ratio of selling, general and administrative expenses to sales in year $t$ to the same ratio in year $t-1$. The following is the formula for calculating the SGAI ratio based on Beneish (1999):

$$
S G A I=\frac{S G A_{t} / \text { Sales }_{t}}{S G A_{t-1} / \text { Sales }_{t-1}}
$$

\section{Leverage Index (LVGI)}

Comparison of the ratio of total debt and total assets in year $\mathrm{t}$ with the same ratio in year $\mathrm{t}-1$. The formula for calculating the LVGI ratio is as follows (Beneish, 1999):

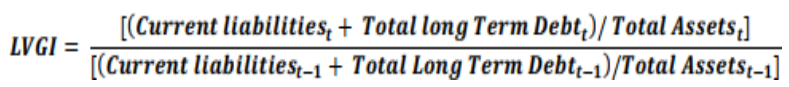

\section{TATA}

Accrual is calculated as change in working capital account other than cash less depreciation. Total accruals or partitions of total accruals were used in previous work to assess the extent to which managers make discretionary accounting choices to change earnings as desired. The formula for calculating the TATA ratio based on Beneish (2012) is as follows

$T A T A=\frac{\left(\text { Income Before Extraordinary Item }_{t}-\text { Cash flow from operation }_{t}\right)}{\text { Total Assets }}$

\section{RESULT}

The purpose of this study was to investigate the effect of tournament incentives on the possibility of fraud in the financial statements of manufacturing companies listed on the Indonesian stock exchange. This study tested 63 data obtained from 7 companies for 6 consecutive years. The data analysis technique in this study used SEM-PLS analysis using the WarpPLS

5.0 software. The results in this study are summarized in the image below.

Figure 1. 2 .

Estimated direct relationship

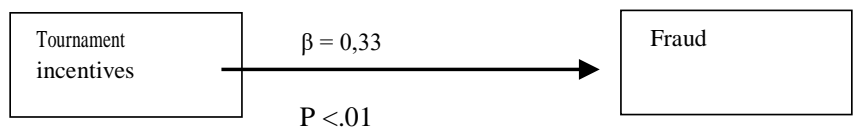

Based on Figure 1. 2 above it can be seen that the tournament incentives to fraud tdalam financial statements have path coefficient value of 0,33 and a $P$ 


\section{Procedia Business and Financial Technology}

Proceedings of the 2 nd International Conference on Business and M anagement of T echnology (ICO N BM T 2020) - Part 2

value of $\mathrm{P}<0.01$ which means that higher levels of incentives tournament then the likelihood of fraud in the financial statements are also high.

Tournament incentives encourage executives to improve their performance in order to be able to achieve the incentives offered. To achieve this target,executives often take deviant actions, such as the tendency to commit fraud in financial reporting so that it can have negative consequences for the company. The results of this study support the results of research conducted by [5].

\section{REFERENCE}

[1] E. P. Lazear and S. Rosen, "Rank- Order Tournaments as Optimum Labor Contracts," Journal of Political Economy, vol. 89, no. 5, pp. 841-64, 2002.

[2] S. L. Sun, A. Habib, and H. J. Huang, "Tournament Incentives and Stock Price Crash Risk: Evidence from China," Pacific Basin Finance Journal, vol. 54, no. September 2018, pp. 93-117, 2019, doi: 10.1016/j.pacfin.2019.02.005.

[3] O. Kini and R. Williams, "Tournament Incentives,
Firm Risk, and Corporate Policies," Journal of $22 / 180$ Financial Economics, vol. 103, no. 2, pp. 350-76, 2012, doi: 10.1016/j.jfineco.2011.09.005.

[4] M. A. M. Haß Lars Helge and S. Vergauwe., "Tournament Incentives and Corporate Fraud," Journal of Corporate Finance, vol. 34, pp. 251-67 101016201507 008, 2015.

[5] N. Jia, "Tournament Incentives and Stock Price Crash Risk," Accounting Horizons, vol. 32, no. 3, pp. 101-21, 2018.

[6] L. A. Bebchuk, K. J. M. Cremers, and U. C. Peyer, "The CEO Pay Slice," Journal of Financial Economics, vol. 102, no. 1, pp. 199-221, 2011.

[7] T. R. Kubick and A. N. S. Masli, "Firm- Level Tournament Incentives and Corporate Tax Aggressiveness," Journal of Accounting and Public Policy, vol. 35, no. 1, pp. 66-8, 2016, doi: 10.1016/j.jaccpubpol.2015.08.002.

[8] J. Chena, H. Honga, and J. C. Stein, "Forecasting Crashes: Trading Volume, Past Returns and Conditional Skewness in Stock Prices," Journal of Financial Economics, vol. 54, no. 6, pp. 2143-84, 2001. 